\title{
Small electron transfer proteins as mediators in enzymatic electrochemical biosensors
}

\author{
Célia M. Silveira \\ REQUIMTE - Dept. Química, Faculdade de Ciências e Tecnologia (UNL), 2829-516 Monte \\ Caparica, Portugal \\ M. Gabriela Almeida ( $\square)$ \\ REQUIMTE - Dept. Química, Faculdade de Ciências e Tecnologia (UNL), 2829-516 Monte \\ Caparica, Portugal \\ Escola Superior de Saúde Egas Moniz, Campus Universitário, Quinta da Granja, 2829-511 Monte \\ Caparica, Portugal \\ Email: mg.almeida@ fct.unl.pt \\ Tel.: +351-212948550; Fax: + 351-212948300
}

\section{Abstract}

Electrochemical mediators transfer redox equivalents between the active sites of enzymes and electrodes and, in this way, trigger bioelectrocatalytic redox processes. This has been very useful in the development of the so-called second generation biosensors, where they are able to transduce the catalytic event into an electrical signal. Among other pre-requisites, redox mediators must be readily oxidized/reduced at the electrode surface and easily interact with the biorecognition component. Small chemical compounds (e.g. ferrocene derivatives, ruthenium or osmium complexes and viologens) are frequently used for this purpose, but lately, small redox proteins (e.g. horse heart cytochrome c) have also played the role of redox partners in biosensing applications. In general, the docking between two complementary proteins introduces a second level of selectivity to the biosensor and enlarges the list of compounds targeted for analysis. Moreover, electrochemical interferences are frequently minimized owing to the small overpotentials achieved. This paper aims to provide an overview of enzyme biosensors that are mediated by electron transfer proteins. The article begins with a few considerations on mediated electrochemistry in biosensing 
systems and proceeds with a detailed description of relevant works concerning the cooperative use of redox enzymes and biological electron donors/acceptors.

Keywords: electrochemical biosensors, redox partner, electron transfer protein, mediated electrochemistry 


\section{Introduction:}

\section{Electron transfer in electrochemical systems}

The electron transfer (ET) between redox centers of proteins is central in biological processes like the respiratory chain, photosynthesis, metabolic pathways (e.g. glycolysis or the citric acid cycle) and even in the regulation of gene expression, where so-called redox switches are involved [1]. Over the past decades electrochemistry has surrendered important information on the mechanisms, kinetics and thermodynamics of ET reactions in biological systems [2]. Besides achieving a better understanding of redox reactions, the study of the electrochemistry of proteins and enzymes provides the basis for the fabrication of electrochemical biosensors, i.e. integrated analytical devices that combine a biorecognition element displaying catalytic activity (enzymes or whole/fragment cells containing enzymes), with an amperometric or voltammetric transducing system $[3,4]$.

Although some enzymes (typically heme and blue copper proteins) exhibit direct electron transfer (DET) on electrode surfaces with about one hundred examples reported in the literature, this is not the common trend [5,6]. Additionally, it is not often that they also display catalytic activity in DET conditions. One of the main reasons is the intrinsic isolating nature of the polypeptide chains that wrap around the redox centers in many protein structures. If cofactors are shielded by the apoprotein, it is very hard to achieve electrochemical communication with electrodes. Modification of electrode surfaces can help protein interaction with transducers, thus facilitating DET and/or electrocatalysis. The modification of electrode interfaces usually consists in conferring a suitable overall charge or specific functional groups that favor the protein's attachment or orientation on the electrode surface (e.g. with bipirydil, poly-L-lysine or self-assembled monolayers (SAMs)) [7-9]. Nevertheless, when looking into enzyme electrocatalysis a common approach is the use of redox mediators, i.e. small electroactive molecules that can easily interact with the protein's redox centers and consequently exchange electrons between electrodes and the biocatalyst. In this way, mediators can provide the means to follow and measure enzymatic reactions by electrochemical methods $[4,10]$. 


\section{Mediated electron transfer}

As aforementioned, the electrical contacting of oxidoreductases that lack DET with electrodes can be established by means of a reversible redox couple, one of the forms of which serves as a co-substrate to the enzyme, as depicted in Fig. 1A $[11,12]$. In mediated electrochemistry (MET), and following an EC' mechanism, the consumption of the redox mediator, i.e. the co-substrate, due to the catalytic reaction is detected as a current amplification (Fig. 1B). Such current increase is directly related to the amount of substrate being processed $[6,13]$.

Fig. 1

Unlike DET, the use of redox mediators takes the control over the protein reaction center away from the electrode [14]. On the one hand, this can be detrimental to the selectivity of detection, since the mediator can react with other species present, and in the case of biosensors, can require a more complex manufacturing process, additional reagents and sophisticated immobilization methods. On the other hand, redox mediation can overcome the frequently sluggish electron communication of enzyme redox centers with electrodes, thus increasing ET rates $[4,14]$.

The mediated transfer of redox equivalents is the working principle of second generation amperometric biosensors (Table 1 briefly compares the three biosensor generations). Mediators are characterized by having a high heterogeneous ET rate that does not compromise electrochemical reversibility and, at the same time, a homogeneous fast electron exchange with the enzyme. Both oxidized and reduced forms should be stable and unreactive with oxygen; also, the reaction should not depend on $\mathrm{pH}$. Furthermore, when selecting a redox mediator for biosensor applications it is important to consider toxicity, biocompatibility, ease of immobilization and, very importantly the redox potentials. Small operating voltages are preferred, allowing appropriate enzyme reaction transduction, while avoiding side reactions. In other words, a mediator should shift redox potentials from the extreme values necessary to detect target analytes, to values around zero, at which fewer interfering species are reduced or oxidized [11,14-16]. 


\section{Table 1}

Over the years, much work has focused on identifying efficient mediators to assure enzyme wiring to electrodes. These are generally organic compounds like viologens, phenazines, quinones, tetrathiafulvalene, tetracyanoquinodimethane or metal complexes such as osmium, ruthenium, ferrocene and derivatives $[4,17,18]$. However, it is not uncommon to find monohemic cytochromes (cyt) and other small proteins as a source or a sink of electrons in mediated electrochemical systems (Fig. 2). In fact, aside the use of physiological electron donors/acceptors to mimic more faithfully charge transfer processes that occur in vivo and thereby study intermolecular ET and enzyme kinetics [19], the enzyme/mediator protein coupling can be also exploited in bioelectroanalytical applications, and this will be the subject matter of the present review.

Fig. 2

At this point, it should be mentioned that the use of small ET proteins as redox mediators in biosensors is not limited to naturally inherent redox pairs. In fact, this very interesting ET route has been scarcely exploited up to now, since the physiological partner of the enzyme must be previously identified and isolated. Alternatively, the reaction between versatile electroactive proteins that are not natural redox partners (e.g. horse heart cytochrome c) has also been be explored for biosensing purposes, as will be discussed below. In such a case, protein pairing is largely empirical.

\section{Protein redox mediators in biosensors}

Protein electron acceptors (or donors) bring some advantages into biosensing. They display high affinity and turnover rates with oxidizing (or reducing) enzymes, specifically if the physiological redox partner is being used [16,27]. Unlike artificial electron shuttles, which are frequently general catalysts and generate unspecific responses, the redox mediation with natural electron shuttles is based on the selective interaction between two complementary proteins, frequently adding a second selectivity element to the biosensor [28]. Also, for in vivo applications ET proteins should be considered instead of artificial redox 
mediators since the first are less likely to be harmful to biological systems $[29,30]$.

In the following sections we report some of the biosensor proposals which combine enzymes with protein redox mediators. The examples are arranged by mediator protein with subsections detailing the enzyme in use and the electrode design. A selected number of cyclic voltammograms from the works referenced herein are shown in Fig. 3, depicting the mediator redox waves and the catalytic currents following substrate additions.

Fig. 3

Many published studies focus on the interaction of mediator proteins and biocatalysts, but disregard the catalytic activity of the bioelectrodes. This survey was only directed towards works with an analytical perspective and/or aiming at future biosensor applications. Actually, this approach could be considered a recent trend in the R\&D of enzyme based biosensing devices, since most of the selected publications report to the last fifteen years.

It must be stressed that, regardless of the proteins couple, the electrode architecture is a very important aspect, since it should guarantee both catalytic turnover and vectorial ET from (or to) the redox enzyme. In particular, the effective immobilization of the small protein mediators and the higher molecular weight enzymes without impairing ET, can be a challenging task. While some approaches make use of simple methods such as entrapment with dialysis membranes [16,34], others integrate the biosensors components with cross-linking agents or polymeric layers [2,33,35-37]. A common trend is also the use of thiolmodified gold electrodes onto which small cytochromes can be attached and display facile DET [37-40]. Nevertheless, some of the reviewed works do not constitute integrated biosensors, because at least one of the components of the mediated system (mediator protein or enzyme) is not immobilized on the electrode [27,29,40-43]. Table 2 summarizes information on the bioelectrode proposals described below, including both protein and non-protein components, as well as the electrode design.

\section{Table 2}




\section{Protein mediators and biosensors:}

\section{Cytochrome c}

Small cytochromes, such as horse heart cytochrome $\mathrm{c}$ are by far the most used protein mediators. Cytochrome $\mathrm{c}$ is a small globular protein (12 kDa) which encompasses a c-type heme. It is involved in the charge transport of the respiratory chain (Fig. 2A). Because it is a basic protein, it interacts well at negatively charged surfaces (e.g. immobilizing matrices, electrode surfaces or redox partner enzymes) through its positively charged lysine residues [36]. This cytochrome can display a well-defined quasi-reversible electrochemistry on electrode surfaces, directly on highly oxygenated carbon surfaces, such as polished edge pyrolytic graphite, or on promoter covered surfaces, such as thiolmodified gold electrodes [39,58,59]. Additionally, good electrochemical responses can be obtained with some polymeric matrices, like Langmuir-Blodget thin films $[2,36]$.

Cyt $\mathrm{c}$ is the physiological redox partner of many redox enzymes, for instance, cytochrome $c$ peroxidase, sulfite oxidase and lactate dehydrogenase. Furthermore, electron mediation by cytochrome $\mathrm{c}$ has been reported with several other enzymes: laccase, ascorbate oxidase [47,60,61], NADPH cytochrome P450 reductase [62], bilirubin oxidase [29,38], xanthine oxidase [46], among others. The role of cyt $\mathrm{c}$ on such electrodes falls on the electron shuttling between proteins and electrodes. As earlier mentioned, it is important for cyt $\mathrm{c}$ to display a fast ET rate with both partners: heterogeneous with the solid electrode and homogenous with the enzymes. This can be favored by electrode modifications which allow optimal orientation but at the same time grant some mobility to the redox molecule, so that it can successfully accomplish molecular docking [43]. Still, cyt c has also displayed effective electron transfer functions when simply entrapped within films where no specific orientation is expected $[2,48,51]$.

\section{Lactate oxidoreductase / Flavocytochrome $\mathbf{b}_{2}$}

Flavocytochrome $b_{2}$ is a lactate oxidoreductase that can be found in yeast mitochondria. It catalyzes the oxidation of L-lactate to pyruvate allowing organism growth on lactate. It is a tetrameric enzyme containing a flavin 
dehydrogenase domain housing a flavin mononucleotide (FMN), and a heme domain comprising a $\mathrm{b}_{2}$-type heme. Cytochrome $\mathrm{c}$ is the physiological electron acceptor for the enzyme $[63,64]$.

An electrochemical study showing mediated ET between cyt c (horse heart) and flavocytochrome $b_{2}$ (yeast) in solution was presented by Cass et al. [41]. Cyt $c$ displayed quasi-reversible electrochemistry in bis(4-pyridyl) disulfide gold modified electrodes. In the presence of flavocytochrome $b_{2}$ and upon addition of L-lactate an increase in catalytic current was observed, consistent with the regeneration of the electrochemical mediating cyt c [41].

Liu et al. demonstrated the direct electrochemistry of a flavodehydrogenase domain of flavocytochrome $b_{2}$ engineered for L-mandelate dehydrogenase activity [2]. Electrocatalysis of the substrate L-mandelic acid could only be achieved using mediator species. A ferrocene derivative was utilized as well as cyt c, with which higher catalytic currents were observed. Both the cyt $\mathrm{c}$ and the enzyme were sequentially deposited and air dried on pyrolytic graphite electrodes (PGEs) followed by the deposition of a poly-L-lysine layer. It was shown that the protein mediator could transfer redox equivalents with both the enzyme and the electrode, thus creating the basis for the development of an amperometric biosensor [2].

\section{Cytochrome c peroxidase}

Another cyt c based biosensor was proposed by De Wael et al. [35]. In this work a gelatin hydrogel was used for the co-entrapment of horse heart cyt $\mathrm{c}$ and Saccharomyces cerevisae cytochrome c peroxidase (CCP), thereby delivering a hydrogen peroxide biosensor. CCPs are heme containing monomeric proteins involved in hydrogen peroxide detoxification [65]. Cyt $\mathrm{c}$ is the natural redox partner for the enzyme's catalytic reduction of hydrogen peroxide to water. Gold electrodes were first modified with a SAM of 6-mercaptohexanol (MH) after which a mixture of hydrogel and proteins was deposited on top of the electrode surfaces. The immobilization of cyt c was aided by the fact that the hydrogel had an overall negative charge to counter its positive charge yet, it remained mobile in the hydrogel. The cyt c/CCP system had a low overpotential operating range, thus presenting itself as a quite selective system for peroxide detection. The biosensor 
had a fast response to $\mathrm{H}_{2} \mathrm{O}_{2}$ within a linear range of 0 to $0.3 \mathrm{mM}$ and a detection limit of $0.01 \mathrm{mM}[35]$.

\section{Cellobiose dehydrogenase}

Cellobiose dehydrogenase $(\mathrm{CDH})$ is an extracellular protein produced in fungi. This monomeric protein is composed of two domains: one carries a flavin adenine dinucleotide (FAD) cofactor (the catalytic center) and the other has a cyt b-type heme. $\mathrm{CDH}$ catalyzes the oxidation of cellobiose and other oligosaccharides using several electron acceptors, including cyt c $[66,67]$.

Fridman et al. have showed that the couple cellobiose dehydrogenase (Phanerochaete crysosporium) and cyt c (horse heart) could be used to measure cellobiose [43]. The latter was adsorbed onto an 11-mercapto-1-undecanoic acid (MUA) modified gold electrode and functioned as charge carrier between $\mathrm{CDH}$ (in solution) and the transducer surface. Authors have proposed that the FAD center in $\mathrm{CDH}$ oxidizes substrate molecules and transfers electrons to oxidized cyt $\mathrm{c}$ through its heme b domain; the reduced cyt $\mathrm{c}$ is then regenerated on the electrode. Although small catalytic currents could be observed in the presence of cellobiose owing to a direct electrochemical response of $\mathrm{CDH}$, when adding cyt c to the electrolyte a clear catalytic redox wave was displayed, attesting the effective vectorial ET from cellobiose via $\mathrm{CDH}$ and cyt $\mathrm{c}$ to the electrode [43].

Sarauli et al. have used cellobiose dehydrogenases from two different fungal sources, Trametes villosa and Corynascus thermophiles, in a study comparing the direct and the cyt $\mathrm{c}$ mediated electrochemistry of $\mathrm{CDH}$ and cellobiose catalysis [40]. The two enzymes were free in solution, whereas cyt c (horse heart) was adsorbed on gold electrode surfaces modified with a SAM of MUA and 11mercapto-1-undecanol (MU). Following the addition of the enzyme's substrate cellobiose - the catalytic currents observed at high $\mathrm{pH}$ (6-7) were shown to be cyt c mediated. However, at more acidic pH (4-5) the dominating ET pathway for the bioelectrode response was established via the heme b of the enzyme, consistent with the direct electrochemistry of $\mathrm{CDH}$. At $\mathrm{pH} \mathrm{6-7,} \mathrm{the} \mathrm{interaction} \mathrm{of} \mathrm{the} \mathrm{two}$ protein domains decreased due to the electrostatic repulsion of deprotonated amino acid residues on the surface of both domains and therefore a cyt c MET was necessary to report the catalysis of cellobiose [40]. 
More recently, $\mathrm{CDH}$ (Trametes villosa) and cyt c (horse heart) could be coimmobilized in the presence of silica nanoparticles in a supramolecular layered architecture used for lactose measurement [44]. For sensor preparation, gold wire electrodes were first modified with MUA and MU onto which cyt c was adsorbed. These electrodes were then incubated alternately with a mix of the proteins (cyt c and $\mathrm{CDH}$ ) and SiNPs. The bioelectrode assemblies had a defined nanostructure, due to the presence of the nanoparticles, since they constituted the scaffold support for the two protein arrangement. Protein co-entrapment was favored by the electrostatic interactions between $\mathrm{CDH}$ (pI 4.3) and cyt c (pI 10). Lactose dependent catalytic currents were followed by cyclic voltammetry and varied linearly with concentrations from 0.01 to $1 \mathrm{mM}$ [44].

\section{Bilirubin oxidase}

In another cytochrome c mediated scheme proposed by Dronov et al., this protein was employed as electron shuttle for Myrothecium verrucaria bilirubin oxidase (BOD) [29]. This multicopper oxidase has four copper centers in a monomeric structure. It is involved in heme metabolism - it catalyzes the oxidation of bilirubin to biliverdin with concomitant reduction of dioxygen to water [68]. BOD displayed DET on thiol-modified gold-electrodes at low $\mathrm{pH}$ values, though not at neutral and physiological $\mathrm{pH}$. Horse heart cyt c could be used as a redox mediator, both in homogeneous solution and immobilized on mixed SAMs of MUA and MU, enabling a fast kinetics for the BOD catalytic reduction of oxygen at neutral $\mathrm{pH}[29]$.

In a different approach, a number of protein multilayer designs combining cyt $\mathrm{c}$ and different enzymes, including BOD, have been reported [38,45-47,49,50]. The bioelectrodes were built using a layer-by-layer self-assembly method. This allowed regulating the amounts of enzyme and protein redox mediator to achieve optimal catalytic activity. The electrostatic interaction between alternating layers of materials containing complementary charged groups was the basis for the protein entrapment. In particular, poly(aniline sulfonic acid) (PASA) was used as a positively charged matrix for cyt c immobilization, which works as ET system. Besides being adsorbed on the polyelectrolyte layers of PASA, the 
electrochemistry of the redox mediator protein was facilitated by the surface modification of gold electrodes with a MUA monolayer and complemented with an additional cyt $\mathrm{c}$ film (the first layer of cyt $\mathrm{c}$ was shown to facilitate further protein adsorption) [69].

The voltammetric characterization of a BOD/cyt c multilayered electrode showed a quasi-reversible electrochemical signal of the small cytochrome. In the presence of oxygen, an increased cathodic current was observed as a result of the enzymatic reduction of oxygen to water. The catalytic current had a linear dependence on the oxygen present in solution [38]. The same research group has later showed that the BOD/cyt c multilayered biosensor could be formed with different forms of cytochrome c, such as human cyt c and some of its mutant variants. Interestingly, the amount of cyt $\mathrm{c}$ immobilized and the activity of the sensor varied significantly with each of the cyt $\mathrm{c}$ forms. Human wild-type cyt $\mathrm{c}$ produced the highest catalytic currents for oxygen reduction [45].

\section{Xanthine oxidase}

Dronov and co-workers proposed a mediated biosensor based on cyt $\mathrm{c}$ and xanthine oxidase (XOD) for hypoxanthine determination [46]. Xanthine oxidases take part in purine metabolism where they catalyze the oxidation of hypoxanthine and xanthine to uric acid. The high molecular weight protein $(300 \mathrm{kDa})$ comprises FAD cofactors, iron-sulfur clusters and molybdenum centers (the catalytic site) [70].

In a work reported by Dronov et al., cyt c (horse heart) was immobilized on a polyanionic electrolyte, PASA, while XOD (cow milk) was adsorbed on the polycationic poly(ethylenimin) [46]. Upon addition of hypoxanthine into the electrochemical cell, an oxidation current could be measured at $150 \mathrm{mV} v s$ $\mathrm{Ag} / \mathrm{AgCl}$. This means that cyt $\mathrm{c}$ was responsible for the charge transfer from XOD to the electrode surface, thus translating a hypoxanthine oxidation into a detectable amperometric current. The electrode's response was found to change linearly with hypoxanthine concentration over the range 0.25 to $5 \mu \mathrm{M}$, with a sensitivity of $0.3 \mathrm{~A} \cdot \mathrm{M}^{-1} \cdot \mathrm{cm}^{-2}$. The sensor had a low working potential less prone to interferents and side reactions. An additional polyelectrolyte membrane (poly(allylamine), PAA) and thermal treatments improved electrode stability, which retained $60 \%$ of its initial activity after 5 days [46]. 


\section{Laccase}

The same strategy was used to develop an oxygen sensor using the system horse heart cyt c and Trametes versicolor laccase [47]. Fungal laccases are multicopper oxidases thought to be related with morphogenesis, fungal plant-pathogen/host interaction, stress resistance and lignin degradation. The enzyme converts oxygen to water in a four electron reduction reaction accompanied by the oxidation of a broad range of substrates, typically phenolic compounds, such as p-dihydroxy phenol [71]. Is spite of not being its physiological electron donor, cyt $\mathrm{c}$ was able to reduce the enzyme, as earlier seen by Sakurai et al. [61]. Later, laccase could be immobilized by electrostatic interactions with the PASA-cyt $\mathrm{c}$ multilayered film. In air saturated solutions the electrode showed an increase in the catalytic cathodic currents consistent with the sequential reduction of cyt c, laccase and oxygen. Although electrodes prepared with only PASA and laccase also displayed catalytic current for oxygen reduction, in the presence of cyt $\mathrm{c}$, the electrocatalytic signal was considerably amplified. The biosensor exhibited a linear response to oxygen and a pH optimum at 4.5 [47].

\section{Sulfite oxidase}

Sulfite oxidase is a dimeric protein which contains, per subunit, a molybdenum cofactor where the catalytic reaction takes place, and a heme $b_{5}$, as an electron acceptor center. Sulfite oxidases are involved in sulfur metabolism and can be found in animals, plants and bacteria. The enzyme catalyzes the oxidation of sulfite to sulfate, the final step in the oxidative degradation of the sulfurcontaining amino acids cysteine and methionine. It is also involved in the detoxification of sulfite and sulfur dioxide. The enzymes's physiological redox partner is cyt c, as it re-oxidizes the heme cofactor generated during the catalytic cycle [72].

Coury et al. reported an electrochemical study in solution where they have showed that sulfite oxidase from chicken liver can deliver electrons to its redox partner cyt c, even though from a different source (horse heart). This enabled the electrical wiring of the enzyme to a pyrolytic graphite electrode (in the presence of sulfite, anodic catalytic currents could be measured) [42]. 
A decade later, a sulfite biosensor based on the same pair of proteins was described by Abass et al. [48] who mixed sulfite oxidase and cyt c within a carbon ink deposited on screen-printed electrodes (CSPE). Following sulfite addition, the enzyme oxidizes it to sulfate in the molybdenum site, electrons are transferred to the heme $b_{5}$ center and then to the reduced cyt $c$, which, in its turn, is re-oxidized by the electrode, generating an anodic current - the analytical signal. In this way, the catalytic sulfite oxidation current could be easily transduced on the biosensor. The sensor was characterized by amperometric measurements at $0.3 \mathrm{~V} v s$ $\mathrm{Ag} / \mathrm{AgCl}$. The response was slow (2-3 min to reach steady state current), but the catalytic current was linear with sulfite between 0.04 and $5.9 \mathrm{mM}$; the detection limit was 4 ppm. Regarding stability, the biosensor was able to maintain its initial response within a 45 day period. The sensors were shown to be useful for sulfite quantification in water samples, although only recovery tests were performed, because the sulfite concentration in the tested samples was below the detection limit. Except for sulfite related anions (e.g. bisulfite), the current response was not affected by the most common environmental interferents. Thus, authors claimed an enhanced selectivity and sensitivity for sulfite determination by using this mediator [48].

A few years later, the same authors proposed a sulfur dioxide sensor using once again the couple sulfite oxidase/cyt c [51]. The amperometric biosensor was similarly constructed, using screen-printing technology. The measurements were based on the principle that sulfur dioxide gas was dissolved in the electrolyte and converted to sulfite ions. These ions then drove the electrocatalytic reaction of sulfite oxidase, with cyt c playing the role of electron acceptor. The sensors were tested at a working potential of $0.3 \mathrm{~V}$ vs $\mathrm{Ag} / \mathrm{AgCl}$. For the optimized configuration the response current was linear from $\mathrm{SO}_{2}$ concentrations of 4 to 50 ppm, the detection limit was $4 \mathrm{ppm}$ and the response time $t_{90 \%}$ was $110 \mathrm{~s}$. Regarding the electrode stability, biosensors stored over 3 months in the fridge were shown to retain their initial activity. Moreover, the sensor showed great promise for continuous monitoring, with no decay in response over a period of $24 \mathrm{~h}[51]$. 
More recently, Dronov and colleagues developed a bioelectrode with a combination of horse heart cyt $\mathrm{c}$ and sulfite oxidase from a different source (human) [31]. A mixture of both proteins was co-adsorbed on gold electrodes previously modified with an alkanethiol promoter layer (MUA and MU) and cyt c. The bioelectrode displayed catalytic currents for the oxidation of sulfite; cyt c was the species responsible for charge transfer between the sulfite oxidase and the electrode (Fig. 3A). The bioelectrode could detect sulfite within a $20 \mu \mathrm{M}-2 \mathrm{mM}$ concentration range, with a $\mathrm{K}_{\mathrm{M}}^{\text {app }}$ of $310 \mu \mathrm{M}$ [31].

Spricigo et al. reported a polyelectrolyte multilayered system, based on sulfite oxidase and cyt c [50]. The bioelectrode preparation reproduced the same protocol described for BOD, XOD, and laccase bioelectrodes, mentioned previously [38,46,47]. Sulfite oxidase (expressed in E. coli) and cytochrome c (horse heart) were adsorbed by alternated incubation with PASA on gold working electrodes which had been firstly modified with MUA and MU and a monolayer of cyt c. The latter could retain mobility within the network, guarantying a simultaneous interaction with the electrode and sulfite oxidase, as proved by the catalytic activity exhibited in the presence of sulfite. The anodic current was dependent on sulfite concentration up to $70 \mu \mathrm{M}$ and the $\mathrm{K}_{\mathrm{M}}{ }^{\text {app }}$ was estimated to be $1 \mu \mathrm{M}$. Curiously, however, a better response was obtained when the two proteins were mixed and adsorbed together, instead of a sequential multilayered sensor [50].

The same research group later improved on the above configuration by optimizing the number of proteins/PASA layers on the electrode, thereby enhancing the biosensor's response to sulfite. This time, electrochemical measurements were performed at $0.1 \mathrm{~V}$ vs $\mathrm{Ag} / \mathrm{AgCl}$. Upon sulfite addition, a steady state oxidation current could be obtained in $90 \mathrm{~s}$. The detection limit was $1 \mu \mathrm{M}$ of sulfite and, as the other analytical parameters of the biosensor, such value could be improved with the number of cyt c/ sulfite oxidase layers. In a 17 layered electrode, the response to sulfite was linear within the range $1-60 \mu \mathrm{M}$, with a sensitivity of 2.19 mA.M ${ }^{-1}$. The apparent $K_{M}$ was estimated to be $77 \mu \mathrm{M}$. Sensor response decreased to $50 \%$ after one week storage. After additional protein protection provided by extra PASA and poly allylamine hydrochloride layers and a heat treatment step, at $40{ }^{\circ} \mathrm{C}$ the sensors were shown to maintained their initial response for three days, with a subsequent $20 \%$ reduction after 5 days of storage at $4{ }^{\circ} \mathrm{C}$. The biosensor 
was tested with wine samples; it offered closed to $100 \%$ recovery rates, in spiked white wine samples, while the sulfite in the more interferent containing red wine samples was harder to quantify, due to unspecific responses [49].

\section{Microperoxidase-11}

\section{Co(II)-protoporphyrin IX reconstituted myoglobin}

Microperoxidase-11 (MP-11) is an 11 amino acid heme polypeptide that consists of the microenvironment of cyt c's active site. This polypeptide was used as redox mediator for a $\mathrm{Co}(\mathrm{II})$-protoporphyrin IX reconstituted myoglobin which catalyzed acetylene dicarboxylic acid reduction [52]. $\mathrm{Co}(\mathrm{II})$-porphyrins act as catalysts for the hydrogenation of acetylenes, presumably by the intermediate formation of a cobalt hydride species [33]. A monolayer of MP-11 was assembled on MUA SAMs on gold electrodes. The electrodes were then treated with the Co(II) myoglobin and cross-linked with glutaraldehyde. Upon the addition of acetylene dicarboxylic acid, an electrocatalytic cathodic current was observed, indicative of the electrocatalyzed hydrogenation of acetylene dicarboxylic acid to maleic acid. The base layer of MP-11 worked as the electron mediator establishing the electrical contact between the $\mathrm{Co}(\mathrm{II})-\mathrm{Mb}$ and the underlying electrode. The device presented a linear response to acetylene dicarboxylic acid up to $80 \mathrm{mM}$ and a Michaelis-Menten constant $\left(\mathrm{K}_{\mathrm{M}}{ }^{\text {app }}\right)$ of $90 \mathrm{mM}$ [52].

\section{Nitrate reductase}

Microperoxidase-11 mediated nitrate reduction of the cytochrome dependent nitrate reductase from Escherichia coli $(E$. coli) was shown for the first time in a study by Narvaez and co-workers [32]. Nitrate reductases catalyze the conversion of nitrate to nitrite in the first step of the nitrate respiration pathway [73]. The proteins have a molybdenum ion as the active site where nitrate reduction occurs [33].

MP-11 was attached on gold electrodes, in the presence 1-ethyl-3-(3(dimethylamino)-propyl)carbodiimide (EDC), by coupling the protein's carboxylic functions to the amine groups of the cysteamine modified electrodes. The cyclic voltammograms of the bioelectrode showed a pair of well-defined 
redox waves from the one electron reduction of MP-11 heme group. In the presence of nitrate reductase and its substrate in solution, enhanced cathodic currents could be measured (Fig. 3B). These were indicative of MP-11 mediation of the catalytic cycle of nitrate reductase. The current showed nitrate dependence up to a concentration of ca. $5 \mathrm{mM}$ reaching saturation after that, according to a Michaelis-Menten kinetic behavior $\left(\mathrm{K}_{\mathrm{M}}{ }^{\text {app }}=2.4 \mathrm{mM}\right)$ [32].

Later, in a follow up approach, the nitrate reductase was integrated on a MP-11 EDC modified gold electrode, and further incubated with glutaraldehyde, thus creating a more stable configuration to be used as a nitrate biosensor. The linear response to nitrate was extended up to $c a .10 \mathrm{mM}$, accompanied by a $\mathrm{K}_{\mathrm{M}}$ app increase to $6.2 \mathrm{mM}[53]$.

\section{Cholesterol oxidase}

A cholesterol biosensor was prepared on gold electrodes using cholesterol oxidase (Pseudomonas sp.) [54]. Signal transduction was attained with microperoxidase11 as the electron transfer mediator. Cholesterol oxidase is a $56 \mathrm{kDa}$ protein involved in the biosynthesis of bile acids. It contains a FAD cofactor in the active site where cholesterol conversion into cholest-4-en-3-one takes place [74].

The biosensor was prepared on gold surfaces with SAMs of 3-mercaptopropionic acid (MPA) and 3-thiopropanol (TP) which were incubated with MP-11 and the condensing agent EDC. MP-11 was in this way covalently immobilized on the electrode. The enzyme was subsequently immobilized as a nanothin film using layer-by-layer adsorption. The thiol/MP-11 electrodes were therefore sequentially dipped in enzyme and anionic polymer poly(styrenesulfonate) solutions allowing the self-assembly of COx multilayers. The current response of the biosensor to the addition of cholesterol was measured by amperometry at $0 \mathrm{~V} v s \mathrm{Ag} / \mathrm{AgCl}$. It presented a linear current response within the concentration range $0.2-3 \mathrm{mM}$ [54].

\section{Synthetic hemoprotein}

A de novo synthesized protein with reconstituted heme groups has been utilized as a mediator to wire enzymes to electrodes [33]. The chemically engineered 
hemoprotein was designed with specific functional units which allow $i$ ) the integration of groups analogous to the heme native sites and $i i)$ the interaction with reagents that facilitate its immobilization on electrode surfaces. The protein was formed by a four-bundle of antiparallel R-helix elements onto which two $\mathrm{Fe}^{\mathrm{III}}$-protoporphyrin IX complexes could be reconstituted (two of the helices included histidine units). For the biosensor construction, gold electrodes were first modified with a cysteamine monolayer followed by coupling of the bifunctional reagent $\mathrm{N}$-succinimidyl-3-maleimidopropionate. A hemoprotein monolayer was then attached to the electrode via covalent linkage of its thiol groups to the maleimide-functionalized gold electrode. Cyclic voltammograms revealed a single reversible pair of peaks with a formal potential of $c a$. $-0.35 \mathrm{~V} v s$ saturated calomel electrode (SCE), that consists of the two overlapping redox reactions of the heme groups from the synthetic hemoprotein [33].

\section{Nitrate reductase}

The de novo synthetic hemoprotein was used in integrated bioelectrocatalytic electrodes for nitrate reduction $[33,55]$. The immobilized engineered protein could form an affinity complex with nitrate reductase from E. coli, which was stabilized by glutaraldehyde, thus yielding an integrated, electrically contacted enzyme film. This protein assembly could be formed due to the electrostatic interaction between the negatively charged enzyme (pI 4.2) and the positively charged synthetic protein, at $\mathrm{pH}$ 7. The resulting bioelectrodes displayed an increased cathodic current upon nitrate addition (Fig. 3C), consistent with the synthetic hemoprotein mediated electrocatalytic reduction of nitrate by nitrate reductase. A linear response could be obtained up to $c a .50 \mathrm{mM}$ of substrate, with $\mathrm{a} \mathrm{K}_{\mathrm{M}}{ }^{\mathrm{app}}$ of $42 \mathrm{mM}[33,55]$.

\section{Co(II)-protoporphyrin-reconstituted myoglobin}

In the same work, Willner and co-workers have also coupled the bifunctional $\mathrm{Fe}(\mathrm{III})$-protoporphyrin de novo synthesized protein with another semisynthetic protein, Co(II)-protoporphyrin-reconstituted myoglobin [33]. The resulting bioelectrode was shown to electrocatalyze the hydrogenation of acetylene dicarboxylic acid to maleic acid. After the reconstitution of the apomyoglobin with $\mathrm{Co}(\mathrm{II})$-protoporphyrin IX, it was interacted with the de novo hemoprotein 
monolayer-electrode and then cross-linked via glutaraldehyde, as described for the nitrate reductase sensor. The electrode's response to acetylene dicarboxylic acid followed a Michaelis-Menten kinetics with a $\mathrm{K}_{\mathrm{M}}{ }^{\text {app }}$ of $80 \mathrm{mM}$ [33].

\section{Cytochrome $b_{562}$}

The cytochrome $\mathrm{b}_{562}\left(\mathrm{cyt}_{\mathrm{t}} \mathrm{b}_{562}\right)$ from Escherichia coli is a $12 \mathrm{kDa}$ protein that can be found in the periplasm (Fig. 2B). Although no physiological partners have been identified so far for this small hemic protein, it is likely involved in intermolecular ET. As opposed to other small cytochromes, such as cyt c, cyt $b_{562}$ does not possess highly charged regions to facilitate its electrostatic docking with redox partners [56].

\section{Glucose oxidase and pyrroloquinoline quinone glucose dehydrogenase}

Okuda et al. made use of cyt $b_{562}$ as an electron carrier in a couple of glucose biosensor systems. Two different enzymes were tested: glucose oxidase (GOx) from Aspergillus nigar and pyrroloquinoline quinone glucose dehydrogenase (PQQ-GDH) from Acinetobacter calcoaceticus [30]. These enzymes are involved in glucose oxidation, catalyzing the conversion of $\beta$-D-glucose into D-glucono1,5-lactone. GOx is a dimeric protein with one bound FAD cofactor per monomer. GOx utilizes oxygen as the electron acceptor of the catalytic reaction with concomitant hydrogen peroxide production [75]. The PQQ-GDH from Acinetobacter calcoaceticus is a soluble protein that can be found in the bacteria's periplasmic space. It is composed of two identical $50 \mathrm{kDa}$ subunits that contain a pyrroloquinoline quinone (PQQ) as prosthetic group. The enzyme converts mono and disaccharides into lactones. Contrary to GOx, it does not require oxygen as electron acceptor; it can donate electrons to small cytochromes, such as cyt $b_{562}$ $[56,76]$.

The bioelectrodes were prepared by mixing the cytochrome and each enzyme in carbon paste. In the presence of glucose, the cyclic voltammograms of these electrode preparations exhibited an increase in current correlated with the glucose concentration (Fig. 3D). Hence, both enzymes could transfer electrons from their redox centers through cyt $b_{562}$. Measurements were performed at potentials close 
to cyt $b_{562}$ reduction potential, i.e. $0.189 \mathrm{~V} v s$ standard hydrogen electrode (SHE). The detection limits of the biosensors were $0.1 \mathrm{mM}$ and $0.8 \mathrm{mM}$, while the quantification ranges spanned for $2 \mathrm{mM}$ and $20 \mathrm{mM}$, for PQQ-GHD and GOx, respectively. The sensitivity was higher with the PQQ-GHD based sensor with $43.2 \mu$ A.M ${ }^{-1} . \mathrm{cm}^{-2}$ versus $12.2 \mu \mathrm{A} . \mathrm{M}^{-1} . \mathrm{cm}^{-2}$ for the GOx biosensor. Because cyt $b_{562}$ was not the natural redox partner of both enzymes, a high ratio cyt $b_{562}$ to enzyme (100 to 1) was used to ensure efficient electrical wiring. Nevertheless, this cytochrome displayed great versatility in achieving ET with both enzymes, showing its potential application in oxidoreductase based sensors free of synthetic mediators [30].

In a previous work also published by Okuda and collaborators, cyt $\mathrm{b}_{562}$ (and cyt $\mathrm{c}$ ) was shown to improve the catalytic efficiency of glucose sensors based on PQQGDH and artificial redox mediators (potassium ferricyanide or 1-methoxy-5methylphenazinium methylsulfate (PMS)) [56]. The authors proposed that the protein mediator interacted with the enzyme and sequentially transferred the received electrons to the artificial electron shuttle. All proteins (cytochromes and PQQ-GDH) were mixed in carbon paste electrodes and fixed with glutaraldehyde. The amperometric response of the biosensors to glucose was registered by monitoring the oxidation of the artificial mediators (in solution) at $0.4 \mathrm{~V}$ and 0.1 $\mathrm{V}$ vs $\mathrm{Ag} / \mathrm{AgCl}$, for ferricyanide and PMS, respectively. While the electrochemical response was in fact mediated by the chemical electron carriers, which could exclude this work from the context of this review, it was made evident that the inclusion of the cytochromes greatly benefitted the bioelectrode's response to glucose; to be precise, a ca. 30 fold increase in catalytic currents was observed in their presence, as compared to a biosensor response based simply on PQQ-GDH and the artificial mediators [56].

\section{Cytochrome c550 $_{55}$}

Cytochrome $\mathrm{c}_{550}$ from Paracoccus denitricans is a small $15 \mathrm{kDa}$ monohemic c-type cytochrome involved in charge transfer (Fig. 2C). It has been indicated as the physiological electron acceptor for quinohemoprotein amine dehydrogenase (QH-AmDH), mediating the ET from the enzyme to the respiratory chain. QH- 
AmDH catalyzes the oxidative deamination of amines (e.g. n-butylamine, methylamine, histamine) to aldehyde and ammonia, allowing organism growth using amines as the sole source of carbon and energy. The enzyme has two heme c groups and a quinone as cofactors in its heterotrimeric structure [77].

\section{Quinohemoprotein amine dehydrogenase}

Yamamoto's et al. have designed a histamine biosensor using QH-AmDH and cyt $\mathrm{c}_{550}$ from Paracoccus denitricans [16]. The cytochrome replays its physiological role mediating the ET between the transducer interface and the enzyme. The two proteins were co-immobilized by means of a dialysis membrane adjusted on the transducing surface. Gold electrodes were treated with bis(4-pyridyl)disulfide in order to attain reversible electrochemistry of the cyt $\mathrm{c}_{550}$. A clear redox wave was observed in the cathodic and anodic scans attributed to a reversible one electron exchange (Fig. 3E). The formal potential for cyt $\mathrm{c}_{550}$ was estimated at $44.5 \mathrm{mV} v s$ $\mathrm{Ag} / \mathrm{AgCl}$. A comparison study on the biosensor's kinetic parameters was performed with the cyt and several artificial mediators (ferricyanide, quinones and phenylenediamines). The physiological mediator proved to be more efficient for enzymatic bioelectrocatalysis both in terms of kinetic parameters, redox potential and heterogeneous electron transfer kinetics. The favorable electrostatic interaction between the two proteins was pointed out as taking part in the superior behavior of this mediated electrochemical system. The amperometric sensor (tested at $0.120 \mathrm{~V} v s \mathrm{Ag} / \mathrm{AgCl}$ ) could be used for two weeks within a range of 500 $\mathrm{nM}$ to $1.5 \mathrm{mM}$ of histamine [16].

\section{Cytochrome $c_{551}$}

\section{cd $_{1}$ nitrite reductase}

$\mathrm{cd}_{1}$ nitrite reductase $\left(\mathrm{cd}_{1} \mathrm{NiR}\right)$ takes part in the denitrification pathway; it reduces nitrite to nitric oxide, being an important endogenous source of this molecule in bacteria. The enzyme can be found in the periplasm as a soluble dimer composed of two $60 \mathrm{kDa}$ subunits. Each subunit contains a $\mathrm{d}_{1}$ - type heme group, where the reduction of nitrite occurs, and a c-type heme involved in ET (accepts reducing 
equivalents from small cytochromes and copper proteins and transfers them to the catalytic center) [73].

Loujou et al. have shown the mediated nitrite reduction activity of Pseudomonas aeruginosa $\mathrm{cd}_{1} \mathrm{NiR}$ through its putative redox partner cytochrome $\mathrm{c}_{551}$ [34]. Cyt $\mathrm{c}_{551}$ is an ET protein which contains one heme group in its small $9 \mathrm{kDa}$ structure (Fig. 2D) [23]. Contrary to cyt c, it is acidic, with a 4.7 isoelectric point (pI); nevertheless, it was able to exhibit a quasi-reversible electrochemical behavior on PGEs (Fig. 3F). This was attributed to favorable interactions of the hydrophobic patch near cyt $\mathrm{c}_{551}$ heme group with the PGE, and to a ring of positive lysine side chains also located near the heme cleft. The formal potential of the redox protein was $305 \mathrm{mV} v s$ normal hydrogen electrode (NHE) [34]. The electron donor protein and $\mathrm{cd}_{1} \mathrm{NiR}$ were secured on the PGEs with a dialysis membrane. With the addition of nitrite, the $\operatorname{cd}_{1} \mathrm{NiR}$ mediated response was dependent on nitrite concentration in agreement to a Michaelis-Menten profile $\left(\mathrm{K}_{\mathrm{M}}^{\text {app }}=20 \mu \mathrm{M}\right)$. Interestingly, no electrocatalytic activity was detected when artificial electron shuttles (ferrocene, benzoquinone and ferricyanide) were employed [34].

\section{Cytochrome $c_{552}$}

\section{cd $_{1}$ nitrite reductase}

In a more advanced approach, a nitrite biosensor based on $\mathrm{cd}_{1} \mathrm{NiR}$ from Marinobacter hydrocarbonoclasticus and its physiological redox partner cyt $\mathrm{c}_{552}$ was proposed by our own research group [28]. Cytochrome $c_{552}$, a homodimeric $20 \mathrm{kDa}$ protein with one c-type heme per monomer, was indicated as the most probable physiological electron donor for the enzyme in $M$. hydrocarbonoclasticus (Fig. 2E) [73,78]. This small cytochrome (pI 6.8) exhibits a quasi-reversible electrochemistry on 4,4'-dithiodipyridine modified gold electrodes (formal potential $265 \mathrm{mV}$ vs NHE) and carbon paste screen-printed electrodes (254 mV vs NHE) [28,78].

The $\mathrm{cd}_{1} \mathrm{NiR}$ and cyt $\mathrm{c}_{552}$ were co-entrapped within a photopolymerisable polyvinyl alcohol (PVA) derivative matrix. The biosensor was developed on disposable CSPEs onto which a mixture of the proteins and the polymer was deposited. Cyclic voltammograms of the bioelectrode showed the quasi-reversible 
electrochemistry of the cytochrome in the absence of nitrite, and intense catalytic currents in its presence (Fig. 3G). Besides enabling intermolecular ET to $\operatorname{cd}_{1} \mathrm{NiR}$, cyt $\mathrm{c}_{552}$ allows settling the work potential at $-0.1 \mathrm{~V}$ (vs $\left.\mathrm{Ag} / \mathrm{AgCl}\right)$, minimizing interference issues. The linear range was determined to be $10-200 \mu \mathrm{M}$, with a detection limit of $7 \mu \mathrm{M}$. The sensitivity, considering the amount of immobilized cyt $\mathrm{c}_{552}$, was $2.49 \pm 0.08 \mathrm{~A} \cdot \mathrm{mol}^{-1} \cdot \mathrm{cm}^{2} \cdot \mu \mathrm{M}^{-1}[28]$.

\section{Pseudoazurine}

Pseudoazurine is a small $(14 \mathrm{kDa})$ bacterial blue copper protein that acts as electron donor for several enzymes (e.g. enzymes in the denitrification pathway) (Fig. 2F) [79]. Pseudoazurine possesses a type-1 copper center close to the protein surface, which facilitates ET with its redox partners [80].

\section{Copper nitrite reductase}

Prospecting a future application in a nitrite biosensor device, the interaction between the copper containing nitrite reductase $(\mathrm{CuNiR})$ and pseudoazurine from Alcaligenes faecalis S-6, both in the soluble form, were studied by Astier et al. [27].

Copper nitrite reductase can be found in the bacteria periplasm where it catalyzes the reduction of nitrite to nitric oxide. It is involved in nitrate respiration as one of the steps of nitrate reduction to dinitrogen in the denitrification pathway. This enzyme is composed by three identical subunits each containing two copper centers: a type- 1 copper center, involved in ET, and a type- 2 copper center, as the catalytic site. Among other small proteins (such as cyt $c_{552}$ ), $\mathrm{CuNiR}$ can use pseudoazurine as its electron donor partner [73].

According to the proposal of Astier and colleagues, the reaction between pseudoazurine and $\mathrm{CuNiR}$ can be electrochemically transduced on gold electrodes modified with cysteine-containing hexapeptides, which create a biocompatible surface for the interaction of the small ET protein [27]. In fact, cyclic voltammograms of pseudoazurine displayed a pair of redox waves consistent with a quasi-reversible electrochemical process and, in the presence of nitrite, the 
enzyme's turnover could be measured (Fig. 3H). The authors also tested an inorganic mediator, ruthenium hexamine, though a more limited linear range of 1$100 \mu \mathrm{M}$ (compared to $0-1500 \mu \mathrm{M}$ with the physiological electron donor) was attained [27].

The same set of physiological redox partners was immobilized by Tepper on SAM-modified gold electrodes using specific DNA tethers [57]. The electrodes were first immersed in the anchor DNA solution, followed by deposition of a 1mercaptohexanol SAM. Pseudoazurine and nitrite reductase where modified with complementary DNA tags which allowed them to hybridize with the gold anchored SH-DNA strands. Such electrode architecture enabled a tight association of the two proteins with the transducer interface but without compromising charge transfer and catalytic turnover. However, this bioelectrode preparation was not characterized from an analytical perspective [57].

\section{Final Remarks and Conclusions:}

Mediated biosensors based on the physiological partners of redox enzymes can simulate the ET cascades typical of biological processes. The efficiency of charge propagation of these natural electron transport systems is a very attractive feature for biosensors development, as proved by the considerable number of publications in this area. Mediators used in this class of biosensors are almost exclusively small hemic proteins, such as horse heart cytochrome $\mathrm{c}$ and bacterial cytochromes (cf. Table 2). The reasons behind this trend are quite obvious; on the one hand, these biomolecules display facile (quasi-reversible) electrochemistry on electrode surfaces. On the other hand, they can shuttle electrons easily, not only to their natural oxidoreductase couples but also to other non-physiologically related enzymes.

The main advantages and drawbacks of protein mediated biosensors are summarized in Table 3.

\section{Table 3}


An important advantage from the joint use of an enzyme and its redox partner is the efficient electrochemical wiring of biocatalysts that otherwise would not be able to interact with electrode surfaces, sometimes even using small electroactive synthetic mediators [34]. This opens up the range of possibilities for enzymes that can be used in biosensors, thereby expanding the list of target analytes.

Other advantages in using natural electron transfer proteins in biosensors are clearly illustrated by the works in which they are directly compared with artificial mediators - the biosensor's performance is superior with the first $[2,16,27]$. In the particular case of the glucose biosensors based on PQQ-GDH, when protein mediators were introduced in the electron relay between the enzyme and the chemical mediator [substrate-enzyme-mediator (cyt $\mathrm{b}_{562}$-ferricyanide/PMS)electrode] the sensor response improved significantly [56]. Curiously, a superior analytical performance in the presence of electron shuttle protein was also attained in $\mathrm{CDH}$ and laccase based bioelectrodes in which the mediated response was compared to their DET based bioelectrocatalysis [43,47].

It is worth emphasizing that protein mediators operate by intermolecular electron exchange in protein-protein complexes [81]. This has several implications on the electrode design. In particular, it is important for the mediator protein to have some mobility within the sensor biofilm. The simplest situations are the bioelectrodes that do not constitute integrated biosensors because proteins are in solution, or the immobilization is achieved with dialysis membranes. In these cases the enzymes and mediator proteins are expected to interact freely $[16,27,34,40-43]$. In fully integrated biosensors, the mobility and coupling between the biomolecules is highly influenced by the type of immobilization method. Several proposals take advantage of the interactions between the redox couples, just relying on the formation of a complex between the primarily immobilized protein mediator and the redox enzyme $[31,52,53]$. In other cases, the addition of cross-linking agents, such as glutaraldehyde, is necessary; this helps stabilizing and integrating the components on the bioelectrode and leads to improved analytical parameters [33,52,53,55,56]. Entrapment into polymeric matrices is quite common as well; the proteins can be simply deposited on the electrode in a mix with the polymer or incorporated on multilayered systems. Frequently, the polymer matrices counterbalance the overall charge of the protein molecules (enzyme, mediator protein or both) thereby improving the 
immobilization efficiency [35,38,45-47,49,50]. However, the most common method to immobilize proteins is through SAMs (Table 2). In fact, the great majority of bioelectrodes are constituted by a primary layer of thiolated SAM onto which the protein electron shuttle is attached [29,31,38,40,43-47,49,50,52]. The choice of SAMs is normally related with the overall charge of the protein mediators. In general, negatively charged MUA or polar $\mathrm{MH}$ are used for positively charged mediator proteins (cyt c and pseudoazurine) and positively charged cysteamine or polar MH are selected for more acidic mediators (MP-11 and $\mathrm{cyt} \mathrm{c}_{550}$ ) (Table 2).

As often mentioned throughout the text, both interfacial and intermolecular ET involves a suitable orientation between redox partners. In other words, the redox proteins should have favorable orientations towards both the electrode and the enzyme, in order to guarantee effective electron shuttling for the protein electrochemistry and the coupled enzyme catalysis [1]. Most proposals have some degree of molecular organization. Structured biofilms may be built through a layer-by-layer method, frequently using thiol-modified gold electrodes, onto which a first layer of cyt $\mathrm{c}$ is adsorbed, followed by the remaining components $[38,44-47,49,50]$. In this way, besides allowing attachment of the redox mediator protein, the underlying SAMs can optimize its orientation on the electrode interface. On the other hand, good results are also attained in less organized biosensor constructions based on mixed carbon pastes or polymeric layers $[2,28,30,49,50,56]$. Perhaps non-structured biofilms are less constraining to the interacting proteins.

Another important advantage comes from the usually low potentials required to drive the electrochemical reactions. This should contribute to an increased selectivity and sensitivity, especially when compared to biosensors that rely on detection of electroactive co-substrates (e.g. $\mathrm{O}_{2}$ or artificial mediators) or products (e.g. $\mathrm{H}_{2} \mathrm{O}_{2}$ ) [61]. With the exception of microperoxidase-11 and synthetic hemoprotein, the majority of protein electron carriers operate in a potential window close to $0 \mathrm{mV}$ vs NHE ( $\pm 200 \mathrm{mV}$ ) (cf. Table 2). As a consequence, some bioelectrodes are reported to be less prone to interferences [46,51], even allowing detection of hydrogen peroxide at around $-200 \mathrm{mV} v s$ NHE [35]. Nonetheless, despite beneficial, the lowered working potentials do not deliver interference free biosensors, as has been pointed out for sulfite biosensors $[48,49]$. 
Some of the examples discussed in this review article indicate that the affinity of the mediator protein to the enzyme is very important for the biosensor's response $[30,45,56]$, with the physiological redox couples generally offering better electrode performances. When the two proteins are not natural redox partners, high protein mediator/enzyme ratios may have to be used to compensate minor responses [30]. Consequently, identification and purification of the natural electron donors/acceptors of the enzymes is highly recommended.

Before concluding, it is worth mentioning that, due to the elimination of the frequently hazardous chemical mediators, protein mediators based biosensors can be viewed as a step forward in the development of more environmentally friendly devices.

From the overall analysis of the works detailed in the present review, we may anticipate a growing and widespread interest on the use of small electron transfer proteins as mediators in electrochemical biosensors. Although a few challenges need to be overcome, they are generally common to the biosensor field.

\section{Acknowledgements:}

CM Silveira thanks the financial support from Fundação para a Ciência e Tecnologia (post-doctoral fellowship SFRH/BPD/79566/2011).

\section{References:}

1. Scheller FW, Wollenberger U, Lei C, Jin W, Ge B, Lehmann C, Lisdat F, Fridman V (2002) Bioelectrocatalysis by redox enzymes at modified electrodes. Rev Mol Biotechnol 82 (4):411-424

2. Liu H, Hill HAO, Chapman SK (2001) Electrochemistry of the flavodehydrogenase domain of flavocytochrome b2 engineered for 1-mandelate dehydrogenase activity. J Electroanal Chem 500 (1-2):598-603

3. Alvarez-lcaza M, Bilitewski U (1993) Mass Production of Biosensors. Anal Chem 65 (11):525A-533A

4. Frew JE, Hill HAO (1987) Electrochemical Biosensors. Anal Chem 59 (15):933A-944A 
5. Ferapontova E, Gorton L (2005) Direct electrochemistry of heme multicofactorcontaining enzymes on alkanethiol-modified gold electrodes. Bioelectrochemistry 66 (12):55-63

6. Leger C, Bertrand P (2008) Direct electrochemistry of redox enzymes as a tool for mechanistic studies. Chem Rev 108 (7):2379-2438

7. Gooding JJ, Hibbert DB (1999) The application of alkanethiol self-assembled monolayers to enzyme electrodes. TrAC, Trends Anal Chem 18 (8):525-533

8. Lojou É, Bianco P (2006) Application of the electrochemical concepts and techniques to amperometric biosensor devices. J Electroceram 16 (1):79-91

9. Noll T, Noll G (2011) Strategies for "wiring" redox-active proteins to electrodes and applications in biosensors, biofuel cells, and nanotechnology. Chem Soc Rev 40 (7):3564-3576

10. Ikeda T, Kano K (2001) An electrochemical approach to the studies of biological redox reactions and their applications to biosensors, bioreactors, and biofuel cells. J Biosci Bioeng 92 (1):9-18

11. Katz E, Shipway AN, Willner I (2007) Mediated Electron-transfer between Redoxenzymes and Electrode Supports. In: Encyclopedia of Electrochemistry. Wiley-VCH Verlag GmbH \& Co

12. Limoges Bt, Moiroux J, Savéant J-M (2002) Kinetic control by the substrate and/or the cosubstrate in electrochemically monitored redox enzymatic homogeneous systems. Catalytic responses in cyclic voltammetry. J Electroanal Chem 521 (1-2):1-7

13. Almeida MG, Serra A, Silveira CM, Moura JJG (2010) Nitrite Biosensing via Selective Enzymes - A Long but Promising Route. Sensors 10 (12):11530-11555

14. Barton SC, Gallaway J, Atanassov P (2004) Enzymatic Biofuel Cells for Implantable and Microscale Devices. Chem Rev 104 (10):4867-4886

15. Ronkainen NJ, Halsall HB, Heineman WR (2010) Electrochemical biosensors. Chem Soc Rev 39 (5):1747-1763

16. Yamamoto K, Takagi K, Kano K, Ikeda T (2001) Bioelectrocatalytic Detection of Histamine Using Quinohemoprotein Amine Dehydrogenase and the Native Electron Acceptor Cytochrome c-550. Electroanalysis 13 (5):375-379

17. Chaubey A, Malhotra BD (2002) Mediated biosensors. Biosens Bioelectron 17 (6-7):441456

18. Heller A (1996) Amperometric biosensors. Curr Op Biotechnol 7 (1):50-54

19. Kano K, Ikeda T (2000) Fundamentals and Practices of Mediated Bioelectrocatalysis. Anal Sci 16:1013-1021

20. Bushnell GW, Louie GV, Brayer GD (1990) High-resolution three-dimensional structure of horse heart cytochrome c. J Mol Biol 214 (2):585-595

21. Arnesano F, Banci L, Bertini I, Faraone-Mennella J, Rosato A, Barker PD, Fersht AR (1999) The Solution Structure of Oxidized Escherichia coli Cytochrome b562. Biochemistry 38 (27):8657-8670 
22. Timkovich R, Dickerson RE (1976) The structure of Paracoccus denitrificans cytochrome c550. J Biol Chem 251 (13):4033-4046

23. Matsuura Y, Takano T, Dickerson RE (1982) Structure of cytochrome c551 from Pseudomonas aeruginosa refined at $1.6 \AA$ resolution and comparison of the two redox forms. J Mol Biol 156 (2):389-409

24. Brown K, Nurizzo D, Besson S, Shepard W, Moura J, Moura I, Tegoni M, Cambillau C (1999) MAD Structure of Pseudomonas nautica Dimeric Cytochrome c552Mimicks thec4 Dihemic Cytochrome Domain Association. J Mol Biol 289 (4):1017-1028

25. Petratos K, Dauter Z, Wilson KS (1988) Refinement of the structure of pseudoazurin from Alcaligenes faecalis S-6 at 1.55 A resolution. Acta Crystallogr B 44 ( Pt 6):628-636

26. Pettersen EF, Goddard TD, Huang CC, Couch GS, Greenblatt DM, Meng EC, Ferrin TE (2004) UCSF Chimera--a visualization system for exploratory research and analysis. J Comput Chem 25 (13):1605-1612

27. Astier Y, Canters GW, Davis JJ, Hill HA, Verbeet MP, Wijma HJ (2005) Sensing nitrite through a pseudoazurin-nitrite reductase electron transfer relay. ChemPhysChem 6 (6):1114-1120

28. Serra AS, Jorge SR, Silveira CM, Moura JJG, Jubete E, Ochoteco E, Cabañero G, Grande H, Almeida MG (2011) Cooperative use of cytochrome cd1 nitrite reductase and its redox partner cytochrome c552 to improve the selectivity of nitrite biosensing. Anal Chim Acta $693(1-2): 41-46$

29. Dronov R, Kurth DG, Scheller FW, Lisdat F (2007) Direct and Cytochrome c Mediated Electrochemistry of Bilirubin Oxidase on Gold. Electroanalysis 19 (15):1642-1646

30. Okuda J, Wakai J, Yuhashi N, Sode K (2003) Glucose enzyme electrode using cytochrome b562 as an electron mediator. Biosens Bioelectron 18 (5-6):699-704

31. Dronov R, Kurth DG, Möhwald H, Spricigo R, Leimkühler S, Wollenberger U, Rajagopalan KV, Scheller FW, Lisdat F (2008) Layer-by-Layer Arrangement by Protein-Protein Interaction of Sulfite Oxidase and Cytochrome c Catalyzing Oxidation of Sulfite. J Am Chem Soc 130 (4):1122-1123

32. Narvaez A, Dominguez E, Katakis I, Katz E, Ranjit KT, Ben-Dov I, Willner I (1997) Microperoxidase-11-mediated reduction of hemoproteins: electrocatalyzed reduction of cytochrome c, myoglobin and hemoglobin and electrocatalytic reduction of nitrate in the presence of cytochrome-dependent nitrate reductase. J Electroanal Chem 430 (1-2):227233

33. Willner I, Heleg-Shabtai V, Katz E, Rau HK, Haehnel W (1999) Integration of a Reconstituted de Novo Synthesized Hemoprotein and Native Metalloproteins with Electrode Supports for Bioelectronic and Bioelectrocatalytic Applications. J Am Chem Soc 121 (27):6455-6468

34. Lojou E, Cutruzzolà F, Tegoni M, Bianco P (2003) Electrochemical study of the intermolecular electron transfer to Pseudomonas aeruginosa cytochrome cd1 nitrite reductase. Electrochim Acta 48 (8):1055-1064 
35. De Wael K, Bashir Q, Van Vlierberghe S, Dubruel P, Heering HA, Adriaens A (2012) Electrochemical determination of hydrogen peroxide with cytochrome c peroxidase and horse heart cytochrome c entrapped in a gelatin hydrogel. Bioelectrochemistry 83:15-18

36. Moretto LM, Bertoncello P, Vezza F, Ugo P (2005) Electrochemistry of cytochrome c incorporated in Langmuir-Blodgett films of Nafion and Eastman AQ 55. Bioelectrochemistry 66 (1-2):29-34

37. Bistolas N, Wollenberger U, Jung C, Scheller FW (2005) Cytochrome P450 biosensors-a review. Biosens Bioelectron 20 (12):2408-2423

38. Dronov R, Kurth DG, Möhwald H, Scheller FW, Lisdat F (2008) Communication in a Protein Stack: Electron Transfer between Cytochrome c and Bilirubin Oxidase within a Polyelectrolyte Multilayer. Angew Chem Int Ed 47 (16):3000-3003

39. Fedurco M (2000) Redox reactions of heme-containing metalloproteins: dynamic effects of self-assembled monolayers on thermodynamics and kinetics of cytochrome c electrontransfer reactions. Coord Chem Rev 209 (1):263-331

40. Sarauli D, Ludwig R, Haltrich D, Gorton L, Lisdat F (2012) Investigation of the mediated electron transfer mechanism of cellobiose dehydrogenase at cytochrome c-modified gold electrodes. Bioelectrochemistry 87:9-14

41. Cass AEG, Davis G, Hill HAQ, Nancarrow DJ (1985) The reaction of flavocytochrome b2 with cytochrome c and ferricinium carboxylate. Comparative kinetics by cyclic voltammetry and chronoamperometry. Biochim Biophys Acta, Protein Struct Mol Enzymol 828 (1):51-57

42. Coury LA, Oliver BN, Egekeze JO, Sosnoff CS, Brumfield JC, Buck RP, Murray RW (1990) Mediated, anaerobic voltammetry of sulfite oxidase. Anal Chem 62 (5):452-458

43. Fridman V, Wollenberger U, Bogdanovskayat V, Lisdat F, Ruzgasf T, Lindgrenl A, Gortonf L, Scheller FW (2000) Electrochemical investigation of cellobiose oxidation by cellobiose dehydrogenase in the presence of cytochrome $\mathrm{c}$ as mediator. Biochem Soc Trans 28:63-70

44. Feifel SC, Ludwig R, Gorton L, Lisdat F (2012) Catalytically active silica nanoparticlebased supramolecular architectures of two proteins--cellobiose dehydrogenase and cytochrome C on electrodes. Langmuir 28 (25):9189-9194

45. Wegerich F, Turano P, Allegrozzi M, Mohwald H, Lisdat F (2011) Electroactive multilayer assemblies of bilirubin oxidase and human cytochrome $\mathrm{C}$ mutants: insight in formation and kinetic behavior. Langmuir 27 (7):4202-4211

46. Dronov R, Kurth DG, Möhwald H, Scheller FW, Lisdat F (2007) A self-assembled cytochrome c/xanthine oxidase multilayer arrangement on gold. Electrochim Acta 53 (3):1107-1113

47. Balkenhohl T, Adelt S, Dronov R, Lisdat F (2008) Oxygen-reducing electrodes based on layer-by-layer assemblies of cytochrome c and laccasse. Electrochem Comm 10 (6):914917 
48. Abass AK, Hart JP, Cowell D (2000) Development of an amperometric sulfite biosensor based on sulfite oxidase with cytochrome c, as electron acceptor, and a screen-printed transducer. Sens Actuators, B 62 (2):148-153

49. Spricigo R, Dronov R, Lisdat F, Leimkühler S, Scheller F, Wollenberger U (2009) Electrocatalytic sulfite biosensor with human sulfite oxidase co-immobilized with cytochrome $\mathrm{c}$ in a polyelectrolyte-containing multilayer. Anal Bioanal Chem 393 (1):225233

50. Spricigo R, Dronov R, Rajagopalan KV, Lisdat F, Leimkuhler S, Scheller FW, Wollenberger U (2008) Electrocatalytically functional multilayer assembly of sulfite oxidase and cytochrome c. Soft Matter 4 (5):972-978

51. Hart JP, Abass AK, Cowell D (2002) Development of disposable amperometric sulfur dioxide biosensors based on screen printed electrodes. Biosens Bioelectron 17 (5):389394

52. Heleg-Shabtai V, Katz E, Willner I (1997) Assembly of Microperoxidase-11 and Co(II)Protoporphyrin IX Reconstituted Myoglobin Monolayers on Au-Electrodes: Integrated Bioelectrocatalytic Interfaces. J Am Chem Soc 119 (34):8121-8122

53. Patolsky F, Katz E, Heleg-Shabtai V, Willner I (1998) A Crosslinked Microperoxidase-11 and Nitrate Reductase Monolayer on a Gold Electrode: An Integrated Electrically Contacted Electrode for the Bioelectrocatalyzed Reduction of NO3-. Chem Eur J 4 (6):1068-1073

54. Gobi VK, Mizutani F (2001) Layer-by-layer construction of an active multilayer enzyme electrode applicable for direct amperometric determination of cholesterol. Sens Actuators B: Chemical 80 (3):272-277

55. Katz E, Heleg-Shabtai V, Willner I, Rau HK, Haehnel W (1998) Surface Reconstitution of a De Novo Synthesized Hemoprotein for Bioelectronic Applications. Angew Chem Int Ed 37 (23):3253-3256

56. Okuda J, Wakai J, Sode K (2002) The application of cytochromes as the interface molecule to facilitate the electron transfer for PQQ glucose dehydrogenase employing mediator type glucose sensor. Anal Lett 35 (9):1465-1478

57. Tepper AWJW (2010) Electrical Contacting of an Assembly of Pseudoazurin and Nitrite Reductase Using DNA-Directed Immobilization. J Am Chem Soc 132 (18):6550-6557

58. Bond AM (1994) Chemical and electrochemical approaches to the investigation of redox reactions of simple electron transfer metalloproteins. Inorg Chim Acta 226 (1-2):293-340

59. Hill HAO, Walton NJ (1982) Investigation of some intermolecular electron transfer reactions of cytochrome c by electrochemical methods. J Am Chem Soc 104 (24):65156519

60. Jin W, Wollenberger U, Bier FF, Makower A, Scheller FW (1996) Electron transfer between cytochrome c and copper enzymes. Bioelectrochem Bioenerg 39 (2):221-225

61. Sakurai T (1992) Kinetics of electron transfer between cytochrome c and laccase. Biochemistry 31 (40):9844-9847 
62. Jin W, Wollenberger U, Kärgel E, Schunck W-H, Scheller FW (1997) Electrochemical investigations of the intermolecular electron transfer between cytochrome $\mathrm{c}$ and NADPHcytochrome P450-reductase. J Electroanal Chem 433 (1-2):135-139

63. Tabacchi G, Zucchini D, Caprini G, Gamba A, Lederer F, Vanoni MA, Fois E (2009) 1Lactate dehydrogenation in flavocytochrome b2. FEBS J 276 (8):2368-2380

64. Xia Z-x, Mathews FS (1990) Molecular structure of flavocytochrome b2 at $24 \AA$ resolution. J Mol Biol 212 (4):837-863

65. Fishel LA, Villafranca JE, Mauro JM, Kraut J (1987) Yeast cytochrome c peroxidase: mutagenesis and expression in Escherichia coli show tryptophan-51 is not the radical site in compound I. Biochemistry 26 (2):351-360

66. Harreither W, Sygmund C, Augustin M, Narciso M, Rabinovich ML, Gorton L, Haltrich D, Ludwig R (2011) Catalytic Properties and Classification of Cellobiose Dehydrogenases from Ascomycetes. Appl Environ Microbiol 77 (5):1804-1815

67. Henriksson G, Ander P, Pettersson B, Pettersson G (1995) Cellobiose dehydrogenase (cellobiose oxidase) from Phanerochaete chrysosporium as a wood-degrading enzyme. Studies on cellulose, xylan and synthetic lignin. Appl Micro Biotech 42 (5):790-796

68. Cracknell JA, McNamara TP, Lowe ED, Blanford CF (2011) Bilirubin oxidase from Myrothecium verrucaria: X-ray determination of the complete crystal structure and a rational surface modification for enhanced electrocatalytic O2 reduction. Dalton Trans 40 (25):6668-6675

69. Lisdat F, Dronov R, Mohwald H, Scheller FW, Kurth DG (2009) Self-assembly of electro-active protein architectures on electrodes for the construction of biomimetic signal chains. Chem Comm (3):274-283

70. Hille R (1996) The Mononuclear Molybdenum Enzymes. Chem Rev 96 (7):2757-2816.

71. Baldrian P (2006) Fungal laccases - occurrence and properties. FEMS Microb Rev 30 (2):215-242

72. Feng C, Tollin G, Enemark JH (2007) Sulfite oxidizing enzymes. Biochim Biophys Acta - Proteins Proteom 1774 (5):527-539

73. Moura I, Moura JJ (2001) Structural aspects of denitrifying enzymes. Curr Opin Chem Biol 5 (2):168-175

74. MacLachlan J, Wotherspoon ATL, Ansell RO, Brooks CJW (2000) Cholesterol oxidase: sources, physical properties and analytical applications. J Steroid Biochem Mol Biol 72 (5):169-195

75. Hecht HJ, Schomburg D, Kalisz H, Schmid RD (1993) The 3D structure of glucose oxidase from Aspergillus niger. Implications for the use of GOD as a biosensor enzyme. Biosens Bioelectron 8 (3-4):197-203

76. Oubrie A, Rozeboom HJ, Kalk KH, Duine JA, Dijkstra BW (1999) The 1.7 A crystal structure of the apo form of the soluble quinoprotein glucose dehydrogenase from Acinetobacter calcoaceticus reveals a novel internal conserved sequence repeat. J Mol Biol 289 (2):319-333 
77. Fujieda N, Mori M, Ikeda T, Kano K (2009) The Silent Form of Quinohemoprotein Amine Dehydrogenase from Paracoccus denitrificans. Bioscien Biotechnol Biochem 73 (3):524-529

78. Lopes H, Besson S, Moura I, Moura JJG (2001) Kinetics of inter- and intramolecular electron transfer of Pseudomonas nautica cytochrome cd 1 nitrite reductase: regulation of the NO-bound end product. J Biol Inorg Chem 6 (1):55-62

79. Najmudin S, Pauleta SR, Moura I, Romao MJ (2010) The 1.4 A resolution structure of Paracoccus pantotrophus pseudoazurin. Acta Crystallogr, Sect F 66 (6):627-635

80. Laming EM, McGrath AP, Guss JM, Kappler U, Maher MJ (2012) The X-ray crystal structure of a pseudoazurin from Sinorhizobium meliloti. J Inorg Biochem:148-154

81. Willner I, Willner B (2001) Biomaterials integrated with electronic elements: en route to bioelectronics. Trends Biotechnol 19 (6):222-230

\section{FIGURE CAPTIONS}

Fig. 1 Schematic representations of the working principle of protein mediated biosensors. A) The enzymatic oxidation (or reduction) of the substrate is linked to the electrochemical oxidation (or reduction) of the mediator; the red arrow indicates the direction of the electron flow in biosensors based on oxidase enzymes and the gray arrow on reductase enzymes. B) Cyclic voltammograms of a redox mediator/oxidoreductase electrode (reversible electrochemical process), recorded (a) in the absence and (b) in the presence of the enzyme's substrate.

Fig. 2 Three-dimensional structures of redox protein mediators used in biosensors. A) horse heart cyt c (1HRC.pdb) [20]; B) Escherichia coli cyt b562 (1QPU.pdb) [21]; C) Paracoccus denitrificans cyt $\mathrm{c}_{550}$ (155C.pdb) [22]; D) Pseudomonas aeruginosa cyt $\mathrm{c}_{551}$ (351C.pdb) [23]; E) Marinobacter hydrocarbonoclasticus cyt $\mathrm{c}_{552}$ (1CNO.pdb) [24]; F) Alcaligenes faecalis pseudoazurine (1PAZ.pdb) [25]. Protein atomic coordinates were obtained from the Brookhaven Protein Data Bank. Structures were prepared with the UCSF Chimera package [26].

Fig. 3 Bioelectrocatalysis mediated by redox proteins. A) Cytochrome c on MUA/MU modified gold co-adsorbed with sulfite oxidase ((a) - without sulfite, (b)-(f) with $60 \mu \mathrm{M}$ to $1 \mathrm{mM}$ sulfite) [31]; B) Microperoxidase-11 on a MUA modified gold ((a) alone, (b) with nitrate reductase, (c) with nitrate reductase and nitrate) [32]; C) Synthetic hemoprotein and nitrate reductase on cysteamine modified gold ((a) without nitrate (b)-(e) with 12 to $68 \mathrm{mM}$ nitrate; Inset: calibration curve for amperometric measurements at $-0.48 \mathrm{~V}$ vs SCE) [33]; D) Cytochrome $\mathrm{b}_{562}$ and GOx incorporated on carbon paste (immobilized: thin line - GOx, dotted line - GOx and bovine serum albumin, dashed line - GOx and cyt $b_{562}$ thick line - GOx and cyt $b_{562}$ and glucose) [30]; E) Cytochrome $\mathrm{c}_{550}$ (membrane bis(4-pyridyl)disulfide modified gold with: solid line - cyt $\mathrm{c}_{550}$, dotted line - cyt $c_{550}, \mathrm{QH}-\mathrm{AmDH}$ and n-butylamine) [16]; F) Cytochrome $\mathrm{c}_{551}$ and $\mathrm{cd}_{1}$ nitrite reductase on membrane PGE in the presence of $5 \mathrm{mM}$ nitrite ((a) without enzyme, (b) $0.25 \mu \mathrm{M}$ enzyme, (c) 1.5 $\mu \mathrm{M}$ enzyme) [34]; G) Cytochrome $c_{552}$ and $\mathrm{cd}_{1} \mathrm{NiR}$ immobilized in PVA on carbon paste screenprinted electrodes (solid line - without nitrite, dashed line - with $10 \mathrm{mM}$ nitrite) [28], H) Pseudoazurine on hexapeptide modified gold ((a) alone, (b) with $\mathrm{CuNiR,} \mathrm{(c)} \mathrm{with} \mathrm{CuNiR}$ and 0.5 $\mathrm{mM}$ nitrite) [27]. Images reprinted with permission from the respective reference. 


\section{TABLES}

Table 1 Generations of enzyme based amperometric/voltammetric biosensors. MET - mediated electron transfer, DET - direct electron transfer

\begin{tabular}{|c|c|c|c|c|}
\hline Generation & ET mode & Elec & ve species & Examples \\
\hline \multirow{2}{*}{$1^{\mathrm{st}}$} & \multirow{2}{*}{ MET } & \multirow{2}{*}{ natural } & co-substrates & $\mathrm{O}_{2}$ \\
\hline & & & products & $\mathrm{H}_{2} \mathrm{O}_{2}$ \\
\hline \multirow{2}{*}{$2^{\text {nd }}$} & \multirow{2}{*}{ MET } & & cial & ferrocene, viologens \\
\hline & & \multicolumn{2}{|c|}{ natural ET molecules } & cytochrome c \\
\hline $3^{\text {rd }}$ & DET & \multicolumn{2}{|c|}{ enzyme redox cofactors } & $\begin{array}{c}\text { laccase, hemoglobin, } \\
\text { peroxidases, } \\
\text { nitrite reductase }\end{array}$ \\
\hline
\end{tabular}




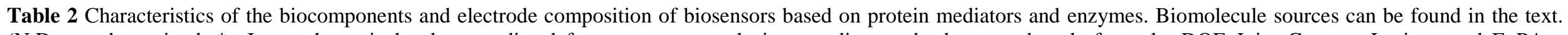

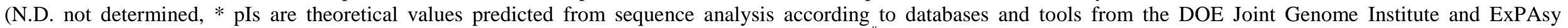
Proteomics Server, ${ }^{\mathrm{f}}$ approximate formal potentials were extrapolated from cyclic voltammograms, ${ }^{\#}$ engineered protein).

\begin{tabular}{|c|c|c|c|c|c|c|c|c|c|c|c|}
\hline $\begin{array}{l}\text { Mediator protein } \\
\text { (cofactor) }\end{array}$ & $\begin{array}{l}\text { MW } \\
(\mathbf{k D a})\end{array}$ & pI & $\begin{array}{l}\text { Enzyme catalyst } \\
\text { (cofactors) }\end{array}$ & $\begin{array}{l}\text { MW } \\
(\mathbf{k D a})\end{array}$ & pI & $\begin{array}{l}\text { Biosensor } \\
\text { analyte }\end{array}$ & $\begin{array}{l}\mathrm{e}^{-} \\
\text {flow }\end{array}$ & $\begin{array}{c}\text { Natural } \\
\text { electron } \\
\text { couple }\end{array}$ & Biosensor design & $\begin{array}{l}\text { Mediator } \mathbf{E}^{01} \text { in } \\
\text { biosensor }\end{array}$ & References \\
\hline \multirow{12}{*}{$\begin{array}{l}\text { Cytochrome c } \\
\text { (heme c) }\end{array}$} & \multirow{12}{*}{12} & \multirow{12}{*}{10} & \multirow[b]{2}{*}{$\begin{array}{l}\text { Lactate oxidoreductase } \\
\left(\mathrm{FMN}, \text { heme } \mathrm{b}_{2}\right)\end{array}$} & \multirow[b]{2}{*}{249} & \multirow[b]{2}{*}{$8.59 *$} & Lactate & $\mathrm{O}$ & yes & Au/disulfide SAM/cyt $\mathrm{c}$ and enzyme in solution & $250 \mathrm{mV} v \mathrm{~s}$ NHE & [41] \\
\hline & & & & & & $\begin{array}{l}\text { L-mandelic } \\
\text { acid }^{\#}\end{array}$ & $\mathrm{O}$ & yes & PGE/cyt c + enzyme + poly-L-lysine & $250 \mathrm{mV} v s \mathrm{SCE}$ & [2] \\
\hline & & & $\begin{array}{l}\mathrm{CCP} \\
\text { (heme c) }\end{array}$ & 40 & $5.95^{*}$ & $\begin{array}{l}\text { Hydrogen } \\
\text { peroxide }\end{array}$ & $\mathrm{R}$ & yes & $\mathrm{Au} / \mathrm{MH} \mathrm{SAM} / \mathrm{cyt} \mathrm{c}+\mathrm{CCP}+$ collagen hydrogel & $18 \mathrm{mV}$ vs SCE & [35] \\
\hline & & & \multirow{3}{*}{$\begin{array}{l}\mathrm{CDH} \\
(\mathrm{FAD}, \text { heme b) }\end{array}$} & 90 & 4.2 & \multirow{2}{*}{ Cellobiose } & \multirow{2}{*}{$\mathrm{O}$} & \multirow{2}{*}{ no } & $\mathrm{Au} / \mathrm{MUA} \mathrm{SAM} / \mathrm{cyt} \mathrm{c} / \mathrm{CDH}$ in solution & $\begin{array}{l}60 \mathrm{mV} v s \mathrm{Ag} / \mathrm{AgCl} \\
(\mathrm{pH} 5)\end{array}$ & [43] \\
\hline & & & & \multirow{2}{*}{$\begin{array}{c}98 / 87 \\
90\end{array}$} & $4.4 / 4.1$ & & & & $\mathrm{Au} / \mathrm{MUA}-\mathrm{MU} \mathrm{SAM} / \mathrm{cyt} \mathrm{c} / \mathrm{CDH}$ in solution & $\begin{array}{l}0 \mathrm{mV} \text { vs } \mathrm{Ag} / \mathrm{AgCl} \\
(\mathrm{pH} 6-7)\end{array}$ & [40] \\
\hline & & & & & 4.3 & Lactose & $\mathrm{O}$ & no & Au/MUA-MU SAM/cyt c/(cyt c + CDH/SiNPs) $)_{n}$ & $50^{\mathrm{t}} \mathrm{mV} v \mathrm{Ag} / \mathrm{AgCl}$ & [44] \\
\hline & & & \multirow{2}{*}{$\begin{array}{l}\text { BOD } \\
(\mathrm{Cu} \text { centers })\end{array}$} & \multirow[b]{2}{*}{64} & \multirow[b]{2}{*}{$5.16^{*}$} & \multirow[b]{2}{*}{ Dioxygen } & \multirow[b]{2}{*}{$\mathrm{R}$} & \multirow[b]{2}{*}{ no } & Au/MUA-MU SAM/cyt c/BOD in solution & $40^{\dagger} \mathrm{mV} v s \mathrm{Ag} / \mathrm{AgCl}$ & [29] \\
\hline & & & & & & & & & $\mathrm{Au} / \mathrm{MUA}$ SAM/cyt c/(cyt c/BOD/PASA $)_{n}$ & $-13 \mathrm{mV}$ vs $\mathrm{Ag} / \mathrm{AgCl}$ & {$[38]$} \\
\hline & & & $\begin{array}{l}\text { XOD } \\
\text { (FAD, Fe-S clusters, } \\
\text { Mo center) }\end{array}$ & 300 & $7.76^{*}$ & Hypoxanthine & $\mathrm{O}$ & no & $\begin{array}{l}\text { Au/MUA SAM/cyt c/(cyt } \\
\text { c/XOD/PASA/poly(ethylenimin) })_{n}\end{array}$ & -12 IIIV DS Ag/ AgC & [46] \\
\hline & & & $\begin{array}{l}\text { Laccase } \\
(\mathrm{Cu} \text { centers })\end{array}$ & 68 & ca. 3.8 & Dioxygen & $\mathrm{R}$ & no & Au/MUA SAM/cyt c/(cyt c/laccase/PASA $)_{n}$ & N.D. & [47] \\
\hline & & & \multirow[t]{2}{*}{$\begin{array}{l}\text { Sulfite oxidase } \\
\text { (Mo center, heme } b_{5} \text { ) }\end{array}$} & \multirow[t]{2}{*}{110} & \multirow[t]{2}{*}{5.5} & Sulfite & $\mathrm{O}$ & yes & $\begin{array}{l}\text { PGE/cyt c and enzyme in solution } \\
\text { CSPE/SO + cyt c + carbon ink } \\
\text { Au/ MUA-MU SAM/cyt c/enzyme + cyt c } \\
\text { Au/MUA SAM/cyt c/(cyt c + enzyme + PASA })_{n}\end{array}$ & $\begin{array}{l}150^{\mathrm{t}} \mathrm{mV} v s \mathrm{Ag} / \mathrm{AgCl} \\
\text { N.D. } \\
-25^{\mathrm{I}} \mathrm{mV} v s \mathrm{Ag} / \mathrm{AgCl} \\
\text { N.D. }\end{array}$ & $\begin{array}{l}{[42]} \\
{[48]} \\
{[31]} \\
{[49,50]}\end{array}$ \\
\hline & & & & & & Sulfur dioxide & $\mathrm{O}$ & yes & CSPE/SO + cyt c + carbon ink & $-125^{\mathrm{t}} \mathrm{mV}$ vs $\mathrm{Ag} / \mathrm{AgCl}$ & [51] \\
\hline \multirow{3}{*}{$\begin{array}{l}\text { Microperoxidase-11 } \\
\text { (heme c) }\end{array}$} & \multirow{3}{*}{1.9} & \multirow{3}{*}{$6.70^{*}$} & $\begin{array}{l}\text { Reconstituted } \\
\text { myoglobin } \\
\text { (Co(II)-protoporphyrin) }\end{array}$ & & & $\begin{array}{l}\text { Acetylene } \\
\text { carboxylic } \\
\text { acid }\end{array}$ & $\mathrm{R}$ & no & Au/MUA SAM/MP-11/enzyme \& glutaraldehyde & $-420^{\mathrm{f}} \mathrm{mV} v s$ SCE & [52] \\
\hline & & & $\begin{array}{l}\text { Nitrate reductase } \\
\text { (Mo centers, Fe-S } \\
\text { clusters) }\end{array}$ & 200 & $6.05 *$ & Nitrate & $\mathrm{R}$ & no & $\begin{array}{l}\text { Au/cysteamine SAM/MP-11 \& EDC/enzyme in } \\
\text { solution } \\
\text { Au/cysteamine SAM/MP-11 \& EDC/enzyme \& } \\
\text { glutaraldehyde }\end{array}$ & $-400 \mathrm{mV}$ vs SCE & $\begin{array}{l}{[32]} \\
{[53]}\end{array}$ \\
\hline & & & $\begin{array}{l}\text { Cholesterol oxidase } \\
\text { (FAD) }\end{array}$ & 56 & $5.98^{*}$ & Cholesterol & $\mathrm{O}$ & no & $\begin{array}{l}\text { Au/MPA-TP SAM/MP-11 \& EDC/(enzyme/ } \\
\text { poly(styrenesulfonate) })_{n}\end{array}$ & $-390 \mathrm{mV}$ vs $\mathrm{Ag} / \mathrm{AgCl}$ & [54] \\
\hline
\end{tabular}




\begin{tabular}{|c|c|c|c|c|c|c|c|c|c|c|c|}
\hline \multirow{2}{*}{$\begin{array}{l}\text { Synthetic } \\
\text { hemoprotein } \\
\text { (Fe(III)- } \\
\text { protoporphyrin X) }\end{array}$} & & & $\begin{array}{l}\text { Nitrate reductase } \\
\text { (Mo centers, Fe-S } \\
\text { clusters) }\end{array}$ & 200 & $6.05^{*}$ & Nitrate & $\mathrm{R}$ & no & \multirow{2}{*}{$\begin{array}{l}\text { Au/cysteamine SAM/synt hemoprotein \& N- } \\
\text { succinimidy-3-malimidopropionate/enzyme \& } \\
\text { glutaraldehyde }\end{array}$} & \multirow{2}{*}{$-350 \mathrm{mV} v s \mathrm{SCE}$} & {$[33,55]$} \\
\hline & & & $\begin{array}{l}\text { Reconstituted } \\
\text { myoglobin } \\
\text { (Co(II)-protoporphyrin) }\end{array}$ & & & $\begin{array}{l}\text { Acetylene } \\
\text { carboxylic } \\
\text { acid }\end{array}$ & $\mathrm{R}$ & no & & & [33] \\
\hline \multirow{2}{*}{$\begin{array}{l}\text { Cytochrome } b_{562} \\
\text { (heme b) }\end{array}$} & \multirow[t]{2}{*}{12} & \multirow[t]{2}{*}{$6.12^{*}$} & $\begin{array}{l}\text { GOx } \\
\text { (FAD) }\end{array}$ & 160 & 4.2 & Glucose & $\mathrm{O}$ & no & $\begin{array}{l}\text { Carbon paste }+ \text { cyt } b_{562}+\text { GOx } \\
\text { Carbon paste }+ \text { cyt } b_{562}+\text { GOx \& glutaraldehyde, } \\
\text { artificial mediators in solution }\end{array}$ & \multirow[t]{2}{*}{$189 \mathrm{mV}$ vs SHE } & $\begin{array}{l}{[30]} \\
{[56]}\end{array}$ \\
\hline & & & $\begin{array}{l}\text { PQQ-GDH } \\
\text { (PQQ) }\end{array}$ & 100 & $8.93 *$ & Glucose & $\mathrm{O}$ & no & Carbon paste + cyt b $b_{562}+$ PQQ-GDH & & [30] \\
\hline $\begin{array}{l}\text { Cytochrome } \mathrm{c}_{550} \\
\text { (heme c) }\end{array}$ & 15 & $4.85^{*}$ & $\begin{array}{l}\text { QH-AmDH } \\
\text { (quinone, heme c) }\end{array}$ & 60 & $4.90^{*}$ & Histamine & $\mathrm{R}$ & yes & $\begin{array}{l}\text { Au/disulfide SAM/ cyt } \mathrm{c}_{550}+\mathrm{QH}-\mathrm{AmDH} / \text { dialysis } \\
\text { membrane }\end{array}$ & $44.5 \mathrm{mV} v s \mathrm{Ag} / \mathrm{AgCl}$ & {$[16]$} \\
\hline $\begin{array}{l}\text { Cytochrome } \mathrm{c}_{551} \\
\text { (heme c) }\end{array}$ & 9 & 4.7 & $\begin{array}{l}\mathrm{cd}_{1} \text { nitrite reductase } \\
\left(\text { heme } \mathrm{c}, \text { heme } \mathrm{d}_{1}\right)\end{array}$ & 120 & $7.75 *$ & Nitrite & $\mathrm{O}$ & yes & PGE/cyt $\mathrm{c}_{550}+\mathrm{cd}_{1} \mathrm{NiR} /$ dialysis membrane & $305 \mathrm{mV}$ vs NHE & [34] \\
\hline $\begin{array}{l}\text { Cytochrome } \mathrm{c}_{552} \\
\text { (heme c) }\end{array}$ & 20 & 6.8 & $\begin{array}{l}\mathrm{cd}_{1} \text { nitrite reductase } \\
\left(\text { heme } \mathrm{c}, \text { heme } \mathrm{d}_{1}\right)\end{array}$ & 120 & 5.05 & Nitrite & $\mathrm{O}$ & yes & CSPE/polyvinyl alcohol + cd $_{1} \mathrm{NiR}+$ cyt $\mathrm{c}_{552}$ & $254 \mathrm{mV}$ vs NHE & [28] \\
\hline \multirow{2}{*}{$\begin{array}{l}\text { Pseudoazurine } \\
\text { (Cu center) }\end{array}$} & \multirow{2}{*}{14} & \multirow{2}{*}{7.8} & \multirow{2}{*}{$\begin{array}{l}\text { Copper nitrite reductase } \\
\text { (Cu centers) }\end{array}$} & \multirow{2}{*}{111} & \multirow{2}{*}{4.5} & \multirow{2}{*}{ Nitrite } & \multirow{2}{*}{$\mathrm{O}$} & \multirow{2}{*}{ yes } & $\begin{array}{l}\mathrm{Au} / \text { cysteine-thiolated hexapeptides/CuNiR and } \\
\text { pseudoazurine in solution }\end{array}$ & $40^{\mathrm{I}} \mathrm{mV}$ vs SCE & [27] \\
\hline & & & & & & & & & $\begin{array}{l}\text { Au/SH-DNA anchors/ MH SAM/DNA tagged } \\
\text { pseudoazurine and } \mathrm{CuNiR}\end{array}$ & $275 \mathrm{mV} v s \mathrm{SHE}$ & [57] \\
\hline
\end{tabular}


Table 3 Advantages and challenges of biosensors based on protein mediators

Pros Cons

- Mimic the efficient charge transfer processes that occur in vivo

- Natural electron transfer proteins have high turnover rates with partner enzymes

- Specific interaction between natural partner proteins may improve sensor selectivity and sensitivity in some cases

- Not limited to physiological redox couples

- Protein mediators usually have low redox potentials (ca. $0 \mathrm{~V}$ vs NHE) enabling

electrochemical reactions at low driving forces

- Biocompatible and nontoxic environmentally friendly mediators
- Effective immobilization while retaining enzymatic catalysis may be difficult

- Intermolecular electron exchange within sensor films requires some protein mobility

- Optimization of electrode interfaces to improve protein favorable orientations

- Complex immobilization methods for small size mediator proteins and higher molecular weight enzymes

- Enzyme natural electron donors/acceptors must be identified

- Purification of a second biomolecule rises the costs

- No direct control over the enzymatic reaction by the electrode 